\title{
elyra
}

\section{Para uma poética dos espaços em branco: Os poemas-colagem de Rui Pires Cabral}

\author{
Joana Matos Frias \\ Universidade do Porto - ILC
}

Resumo: Leitura teórico-crítica das últimas obras de Rui Pires Cabral (Biblioteca dos Rapazes, 2012; Álbum, 2013; Broken, 2014; Oh! LUSITANIA, 2014; Elsewhere/Alhures, 2015), à luz da poética gradualmente enunciada pelo autor ao longo da sua obra anterior composta a partir de Geografia das Estações (1994), com vista a uma tentativa de sistematização dos procedimentos intertextuais e interartísticos constitutivos dos volumes em análise - procedimentos maioritariamente enquadrados no âmbito de formas contemporâneas de montagem e de colagem -, enquanto resultados do entendimento intermedial e intermaterial do ofício poético veiculado pelo artista desde o início da sua produção.

Palavras-chave: Rui Pires Cabral, colagem

Abstract: Theoretical and critical reading of the last works of Rui Pires Cabral (Biblioteca dos Rapazes, 2012; Álbum, 2013; Broken, 2014; Oh! LUSITANIA, 2014; Elsewhere/Alhures, 2015), in the light of a poetics gradually enunciated by the author throughout his previous work, since Geografia das Estações (1994), aiming to systematize the intertextual and interartistic procedures that constitute the volumes under review procedures mainly framed within contemporary forms of assembly and collage - as results of an intermedial and intermaterial understanding of the poetic craft conveyed by the artist from the beginning of his production.

Keywords: Rui Pires Cabral, collage 
J'ai seulement fait ici un amas de fleurs étrangères, n'y ayant fourni du mien que le filet à les lier.

Montaigne, "De la physionomie"

[...]

Every exciting letter has enclosures,

And so shall this---a bunch of photographs,

Some out of focus, some with wrong exposures,

Press cuttings, gossip, maps, statistics, graphs;

I don't intend to do the thing by halves.

I'm going to be very up to date indeed.

It is a collage that you're going to read.

I want a form that's large enough to swim in,

And talk on any subject that I choose,

From natural scenery to men and women,

Myself, the arts, the European news:

And since she's on a holiday, my Muse

Is out to please, find everything delightful

And only now and then be mildly spiteful.

$[\ldots]$

W. H. Auden, "Letter to Lord Byron"

It is largely assumed that all media are created equal, but some media nevertheless remain "more equal" than others.

Jan Baetens

Em 1964, António Aragão, num dos textos programáticos que nos Cadernos da Poesia Experimental dedicou à dilucidação do seu conceito de "Poesia encontrada" (ressonância e revitalização literária dos ready-made e ready-found plásticos de Marcel Duchamp), defendia iluminadoramente o seguinte: 
A poesia sempre variou de expressão. Por um lado, a descoberta duma dada expressão corresponde a uma aquisição instrumental necessária para servir aquilo que o poeta em dado momento tem para dizer. A busca incessante de expressões diferentes, como se passa afinal em todas as artes, é tremendamente provocada pela necessidade de conhecer e dar as realidades (todas) do espírito humano. Sem dúvida que a conquista de outras expressões em vez de destruir a poesia, é afinal a sua maneira de caminhar no tempo, e é o seu contínuo e inesgotável poder de metamorfose que lhe confere valIDADE e presença no mundo. (Aragão 1964: 37)

Não irei, aqui, debruçar-me sobre a obra desse poeta de ofício múltiplo que foi António Aragão, embora o nome e a obra dele certamente acabem por reaparecer ao longo destas considerações, dada a decisiva importância histórico-literária ou histórico-artística que o seu trabalho teve num entendimento verdadeiramente intermedial da criação. Interessa-me fundamentalmente, como ponto de partida, reter este aspecto da sua reflexão, pois nele parece estar sintetizado um dos princípios mais importantes daquilo sobre que gostaria de reflectir: "a conquista de outras expressões em vez de destruir a poesia, é afinal a sua maneira de caminhar no tempo, e é o seu contínuo e inesgotável poder de metamorfose que lhe confere validade e presença no mundo". Aragão denuncia aqui um dos problemas cruciais da história da poesia, o da "legitimação", cujo processo moderno e contemporâneo Silvina Rodrigues Lopes sistematizou já de forma tão decisiva no seu estudo $A$ Legitimação em Literatura, onde chamou a atenção para o facto de nas sociedades modernas o aparecimento da Literatura ter correspondido "à necessidade de salvaguardar a possibilidade de um tipo de discurso que escap[ass]e à exigência absoluta da legitimação". "Mas isso não significa", no enten der da autora, "que a literatura se exclua dos processos de legitimação, uma vez que ela não exclui a compreensão; significa, sim [e é isto que me interessa ressaltar], que se salvaguarda a possibilidade de existência de um género de discurso que nunca perde uma certa margem de estranheza que nele marca a sua irredutibilidade à cultura, [...], a sua não-contemporaneidade, o por vir que o atravessa" (Lopes 1994: 114). Falemos então, não de casas, como gostaria Herberto Helder, mas apesar de tudo de uma morada: a poesia, no seu inesgotável poder de metamorfose que lhe assegura sempre essa margem de estranheza que é a razão mesma do seu poder de resistência a um tipo de lugar muito específico: o lugar-comum, esse que nunca compreenderá a razão de ser das "paisagens inclinadas". 
Quando encaramos a obra do poeta Rui Pires Cabral como uma totalidade, o princípio da metamorfose parece impor-se com a força de uma evidência que é desde logo de ordem material, para tomar rápidos contornos de ordem textual: de um lado, o volume precisamente intitulado Morada, publicado em 2015 pela Assírio \& Alvim, que reúne os livros do autor desde Geografia das Estações, de 1994, até Evasão e Remorso, de 2013, bem como alguns poemas dispersos e inéditos; do outro lado, um conjunto de 6 livros publicados entre 2012 e 2015, intencionalmente excluídos daquela colectânea: Biblioteca dos Rapazes (2012), Broken, Stardust e Álbum (2013), Oh! LUSITANIA (2014), e Elsewhere/Alhures (2015). A diferença óbvia entre estes livros e a obra reunida em Morada é de natureza gráfica: apesar de Morada conter reproduções de obras plásticas de Daniela Gomes e, na capa, de uma colagem de Martin Copertari, estes objectos desempenham uma função paratextual que Ihes preserva a autonomia e a dos textos que acompanham, sendo assumidamente da autoria de outros artistas, que os assinam; os outros seis livros, pelo contrário, apresentam uma configuração da página e uma organização da mancha gráfica que exige uma leitura verdadeiramente tabular, pois não há qualquer possibilidade de se dissociar, nem por algum gesto fenomenológico radical, o que é da ordem verbal e o que é da ordem pictural. Quer dizer que, num plano imediato, a primeira consequência da leitura nos conduzirá à constatação elementar de que o poeta Rui Pires Cabral sofreu uma metamorfose, ou pelo menos uma anamorfose, no sentido da criação de objectos que já não podemos qualificar pacificamente como apenas "poéticos". O problema teórico-crítico agudiza-se perante as breves explicações que todos estes livros apresentam, na abertura ou no final. Destacarei, para começar, a "Nota do Autor" que abre Biblioteca dos Rapazes:

Os poemas que compõem este livro foram inspirados por velhos romances de aventuras e exemplares diversos de literatura juvenil, maioritariamente editados entre as décadas de 30 e 70 do século passado. E quando digo inspirados, digo-o no sentido mais material possível, já que muitos dos versos publicados nestas páginas foram originariamente compostos com palavras e expressões recortadas desses mesmos livros [...] Quanto às imagens que complementam os textos - e a ideia fundamental deste livro foi, desde o início, a de casar a poesia com a colagem -, são de natureza e proveniência muito variadas: revistas e postais antigos, fotografias de anónimos, velhas enciclopédias juvenis, calendários, monografias fotográficas de cidades estrangeiras, além das estampas e ilustrações dos livros acima referidos. (Cabral 2012: 5) 
"Palavras e expressões recortadas" dos livros, introdução manual na página "com tesoura e cola", "casar a poesia com a colagem", "cortar e rasgar" são actos oficinais que virão a ser analogamente enunciados nos livros subsequentes, onde o poeta fala em "palavras extraídas" (Broken), "poemas [...] escritos com palavras recortadas do livro" (Oh! LUSITANIA), "colagens \& poemas" (Elsewhere/Alhures) ou "poemas-colagens". Antes de nos debruçarmos mais detalhadamente sobre as implicações poéticas e artísticas desta estratégia estruturante de hibridização, partamos de três princípios que parecem ser bastante elucidativos no que concerne a historicidade desta obra: 1 . a intertextualidade explícita é um procedimento dialógico que configura o discurso poético de Rui Pires Cabral desde os seus primeiros livros, nomeadamente nos casos emblemáticos de Música Antológica (1997) e Oráculos de Cabeceira (2009); 2. a consciência gráfica do valor visual da poesia é uma constante na obra de Rui Pires Cabral; 3. a colagem faz parte da prática artística de Rui Pires Cabral pelo menos desde os anos da sua estreia literária.

Não me deterei agora no primeiro destes aspectos, uma vez que ele foi já discutido pela investigadora brasileira Tamy Pimenta no seu ensaio "Apropriação e indeterminação na poesia de Rui Pires Cabral" (Pimenta 2015), mas não quero deixar de assinalar aquilo que, nele, me parece determinante para a compreensão aprofundada da obra como um todo: se é certo que os processos de apropriação de discursos alheios nos primeiros livros do autor são eminentemente intertextuais, uma vez que se fundam na convocação citacional de fragmentos retirados na sua maior parte de títulos e letras de canções pop-rock dos anos 80, não é menos certo que essa convocação se inscreve já numa estratégia claramente intermedial, porquanto essas citações abrem cada um dos poemas, não para objectos circunscritamente verbais, mas para expressões artísticas musicais, o que faz delas, de acordo com a tipologia proposta por Irina O. Rajewski no seu estudo sobre "intermedialidade, intertextualidade e remediatização", exemplos óbvios de referências intermediais: as referências intermediais, sublinha Rajewsky, devem ser entendidas enquanto estratégias constitutivas de sentido que contribuem para a significação geral do produto, que assim usa os seus próprios meios, quer para se referir a uma obra individual produzida noutro meio, quer para se referir a um subsistema medial específico ou a outro meio enquanto sistema, solução que talvez explique ainda o facto de Pires Cabral ter 
intitulado "Mixtape" a secção onde reúne 13 textos avulsos (cf. Rajewsky 2005; cf. Cabral 2015: 342 ss.). A especificidade deste tipo de relação intermedial, e aquilo que em última instância está na base da sua diferença efectiva face aos poemas-colagem de que aqui nos ocupamos, é que, embora no primeiro caso o poema se constitua em parte ou na íntegra no vínculo que estabelece com a obra ou sistema que convoca, na referência intermedial há apenas um meio que se encontra materialmente presente, i. e., o poema enquanto objecto verbal, materialidade unívoca que os poemas-colagem claramente vêm ameaçar e suprimir, confrontar e substituir.

Ora, talvez seja então mais interessante destacar que, malgrado um certo efeito de tranquilidade visual que a mancha gráfica do volume Morada inevitavelmente provoca, tal tranquilidade se vê logo ameaçada quando, nas páginas de Geografia das Estações, primeiro livro da colectânea, encontramos o seguinte poema (idem: 25):

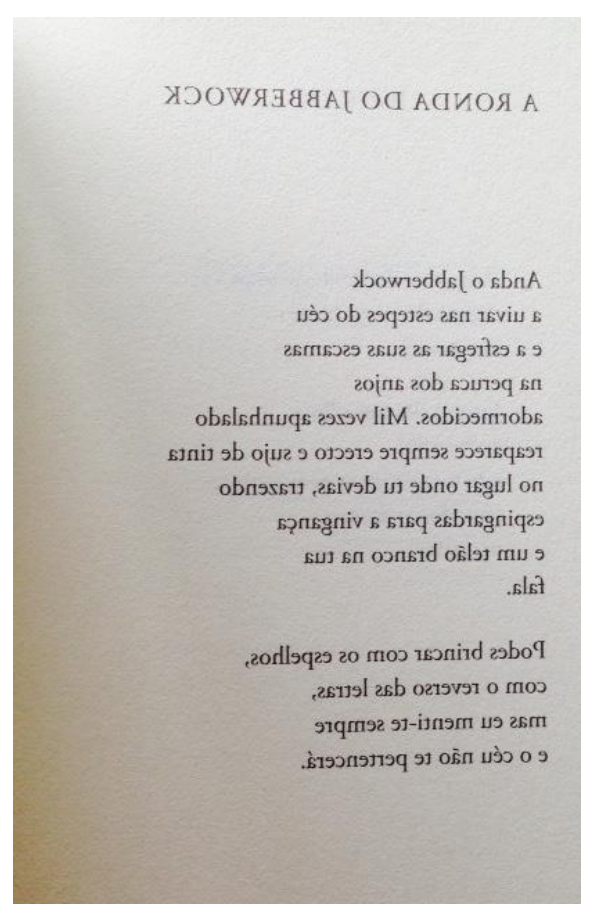

Rui Pires Cabral solicita e revitaliza o famoso episódio da obra de Lewis Carroll, Alice do Outro Lado do Espelho, em que Alice se depara com um livro que a obriga a constatar que se encontra num mundo invertido que também lhe exige uma leitura especular, o que ela faz ao pegar justamente num espelho através do qual reconstitui a textualidade em positivo 
dos versos que compõem um dos mais conhecidos poemas nonsense de Carroll, "Jabberwocky". Ao fazê-lo a poucas páginas do início da sua obra, Pires Cabral denuncia ou anuncia a extrema consciência dos valores de iconicidade e de picturalidade que o texto poético frequentemente patenteia, concretizando assim na materialidade sintácticodiscursiva que joga com a linearidade do significante aquilo que havia já enunciado em alguns versos anteriores, como "as palavras repousam fermentadas / na geometria do meu lagar" (idem: 17), ou "Vê como se cruzam as letras / sobre a verdade do nosso momento" (idem: 22). Em certa medida, este exercício parece ser o correlato verbal da vertigem geo- e topográfica que a arte da memória desta poesia recorrentemente deflagra, e que os versos "A bela geometria das superfícies", de Praças e Quintais, de 2003, ou "nas grandes superfícies / da memória", de Longe da Aldeia, de 2005, poderiam resumir (idem: 137 e 214) ${ }^{1}$. A meu ver, todavia, trata-se sobretudo da evidenciação de uma poética que, ainda que ancorada desde muito cedo em frequentes referências musicais, assume o estatuto visual do texto como essencial à constituição deste enquanto objecto estético, vínculo que talvez explique integralmente o significado de versos como "Tudo o que existe no quarto te fala / com a voz desfigurada do poema" (idem: 148). É com certeza por isso que a composição "Espaços em branco", a meio da obra e do livro Longe da Aldeia, parece imporse com a força programática de uma arte poética, onde podemos ler:

\author{
$[\ldots]$ \\ há em toda a parte um sossego abstracto, \\ as ruas parecem pintadas - betão entre \\ as árvores - numa tela baça. Vamos por lugares \\ que não reconheço, a minha geografia é vaga \\ e omissa como a dos velhos cartógrafos \\ que desenhavam um mundo cheio de espaços \\ em branco. É onde estamos agora, num \\ intervalo do mapa rente à primeira manhã - \\ [...] (idem: 209)
}

Mais adiante, o poeta dará expressão efectiva a esta geografia poética preenchida por espaços em branco, no texto que encerra "A pocket guide to birds" (idem: 320): 
Joana Matos Frias

MUTE SWAN

elyRa , 7, 06/2016: 305-329 - ISSN 2182-8954 | http://dx.doi.org/10.21747/21828954/ely7a16 
"Mute swan" é o exemplo emblemático na poesia daquilo que a Física contemporânea tem qualificado como o "vazio fecundante", e que Michel Cassé resumiu nos seguintes termos, propondo que existem "duas maneiras de pintar o vazio: vê-lo como geometria ou vê-lo como flor":

\footnotetext{
Diremos do vazio [...] que ele é o estado minimal de ser, o estado de energia mínima do sistema de campos que constitui o mundo, o espaço sereno, o repouso invisível dos campos. As suas excitações são as partículas de que são feitas as nuvens, as estrelas, e os homens [e os poemas]. [...] damo-nos assim a liberdade de considerar que a energia minimal do vazio não é forçosamente nula, o que significa atribuir-Ihe um conteúdo. E afectando-Ihe uma energia não nula, damos-Ihe uma hipótese de evoluir. Cosmos de que todas as excitações maiores teriam sido retiradas, o vazio não é a morte, nem a ausência, nem poderia ser assimilado ao nada. Ele aparece, pelo contrário, como um meio florescente, sede e propagador de acção, uma estrutura que determina as propriedades da matéria que ela acolhe como uma vila acolhe os seus habitantes. (Cassé 1993: 167-168; trad. minha)
}

Para aquilo que mais particularmente nos interessa, importa talvez acrescentar que a estratégia de Rui Pires Cabral em “Mute swan”, similar às de John Cage em 4'33 ou de João César Monteiro em Branca de Neve, se por um lado demonstra a natureza verbivocovisual da poesia ao fazer equivaler a supressão do discurso à página em branco (isto é: ao cisne branco, "pour fêter sa blancheur qu'il admire", como em Mallarmé) e a página em branco ao silêncio (literalizando o "mute swan"), por outro lado, não menos importante, demonstra a potencialidade pregnante do fundo sobre que habitualmente o poema se inscreve, dando visibilidade e materialidade a esse fundo, e provocando assim uma inevitável indistinção entre o valor significativo da página e o do texto ("À I'heure où toute forme est un spectre confus", permanecendo a significação "entre dois firmamentos"): gesto semiológico que, em última instância, virá a estar na base da composição material dos poemas-colagem dos livros mais recentes.

Ou seja: preservar esse "vazio fecundante" que na poesia o silêncio ou o branco da página representam, como acontece em "Mute swan", equivale a conferir estatuto de signo ao que habitualmente é da ordem do "não-signo", já que "o vazio é vazio de qualquer coisa tal como a consciência é consciência de alguma coisa" (Ezquerro 2010). "E para que servem / 
os versos / senão para trair / este silêncio branco?", lemos numa das colagens da série "Desenganos":
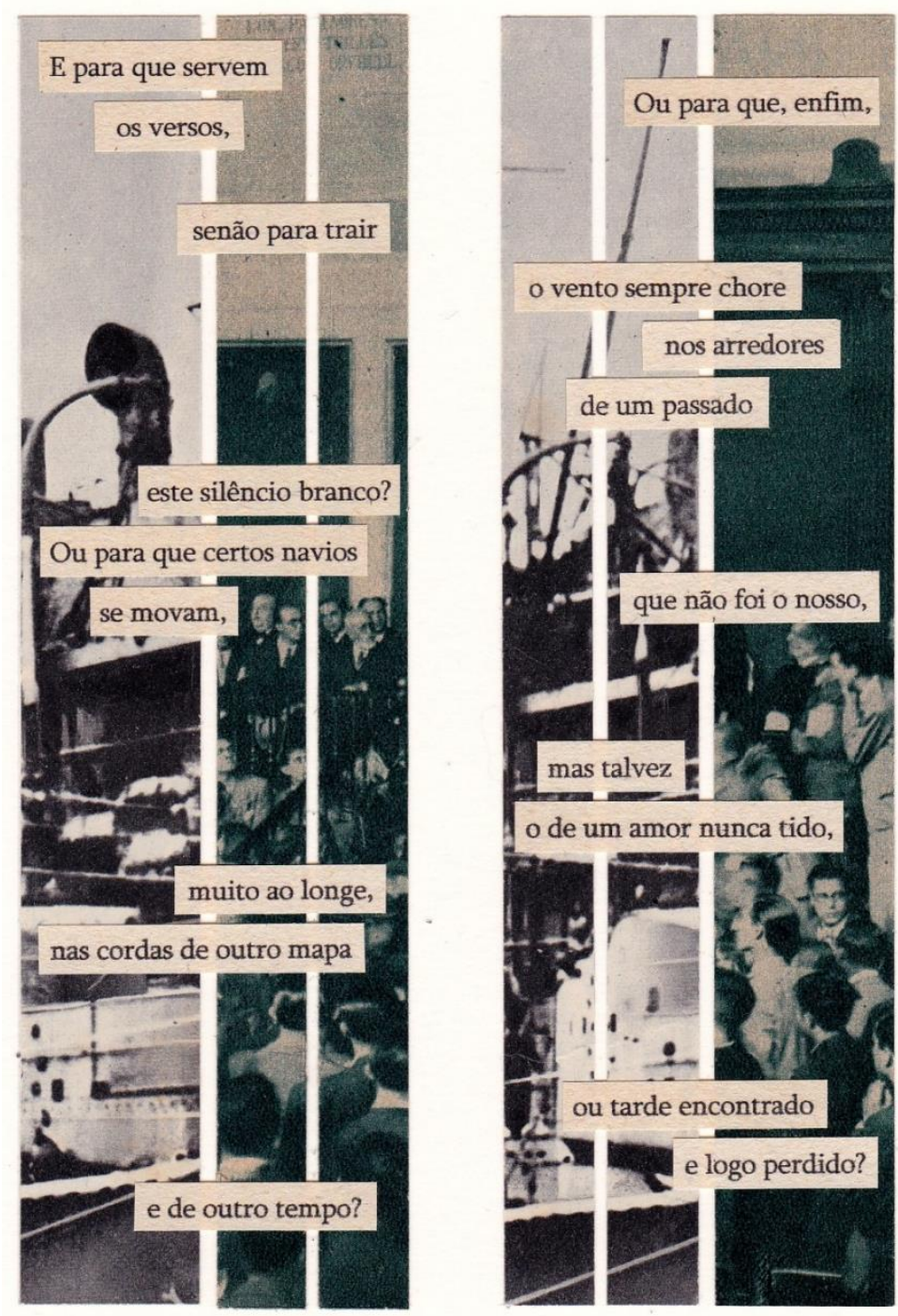

(Cabral 2014a: 143)

Como evidenciou Milagros Ezquerro na sua problematização dos processos textuais de hibridização fecunda, nesta perspectiva "o branco textual não seria aquele fundo neutro, indiscriminado, insignificante, que temos o hábito de considerar, ou de nem sequer considerar, mas um campo [...] de virtualidades em que são susceptíveis de tomar forma todos os tipos de sistemas de significação", como de resto bem sabia Mallarmé (Ezquerro 2010: 8; trad. minha). 
Chegados aqui, em que medida é que tal processo nos poderá ajudar numa melhor compreensão destes livros-objecto que compõem a fase mais recente da produção de Rui Pires Cabral? Desde logo, a partir de uma premissa que está na base do processo de colagem tal como historicamente ele se desenvolveu no campo das artes plásticas a partir do método dos papiers collés praticado por Picasso e Braque e prolongados nos merz de Kurt Schwitters: num plano imediato, o que a collage veio alterar na composição do quadro foi justamente a correlação entre a forma e o fundo, ou entre a figura e o fundo, conforme sublinhou Rosalind Krauss no seu importante ensaio "In the name of Picasso": "se uma das estratégias formais que se desenvolve a partir da colagem", assinala Krauss, "é a insistência na reversibilidade figura/fundo e a transposição contínua entre a forma negativa e a positiva, este recurso formal deriva do comando pela colagem da estrutura de significação"; assim, estamos perante "uma superfície que é a imagem da superfície erradicada. É esta erradicação da superfície original e a reconstituição dela através da figura da sua própria ausência que é o termo principal de toda a condição da colagem como um sistema de significantes" (Krauss 1981: 16; trad. minha)². Quer dizer, o que está em causa são os limites da iconicidade, motivo pelo qual Picasso e Cocteau defenderão que na collage se trata, já não de um trompe l'oeil mas de um trompe l'esprit ${ }^{3}$. Uma vista de olhos muito rápida sobre as três colagens que Rui Pires Cabral publicou no seu site (http://poemacolagem.tumblr.com/) com a data de 1994 - ano de publicação de Geografia das Estações, que figura actualmente como o primeiro livro da obra poética - permitir-nos-á constatar facilmente que o próprio Autor começou por criar colagens claramente inscritas numa tradição plástica, e não poética. Cobra e $O$ Céu não nos pertencerá são duas colagens entre a tradição cubista e a dada de inclinações expressionistas, em que a inserção de um objecto verbal corresponde apenas ao gesto do recorte e da colagem de um material pré-existente e discursivamente mutilado em virtude desse gesto; 

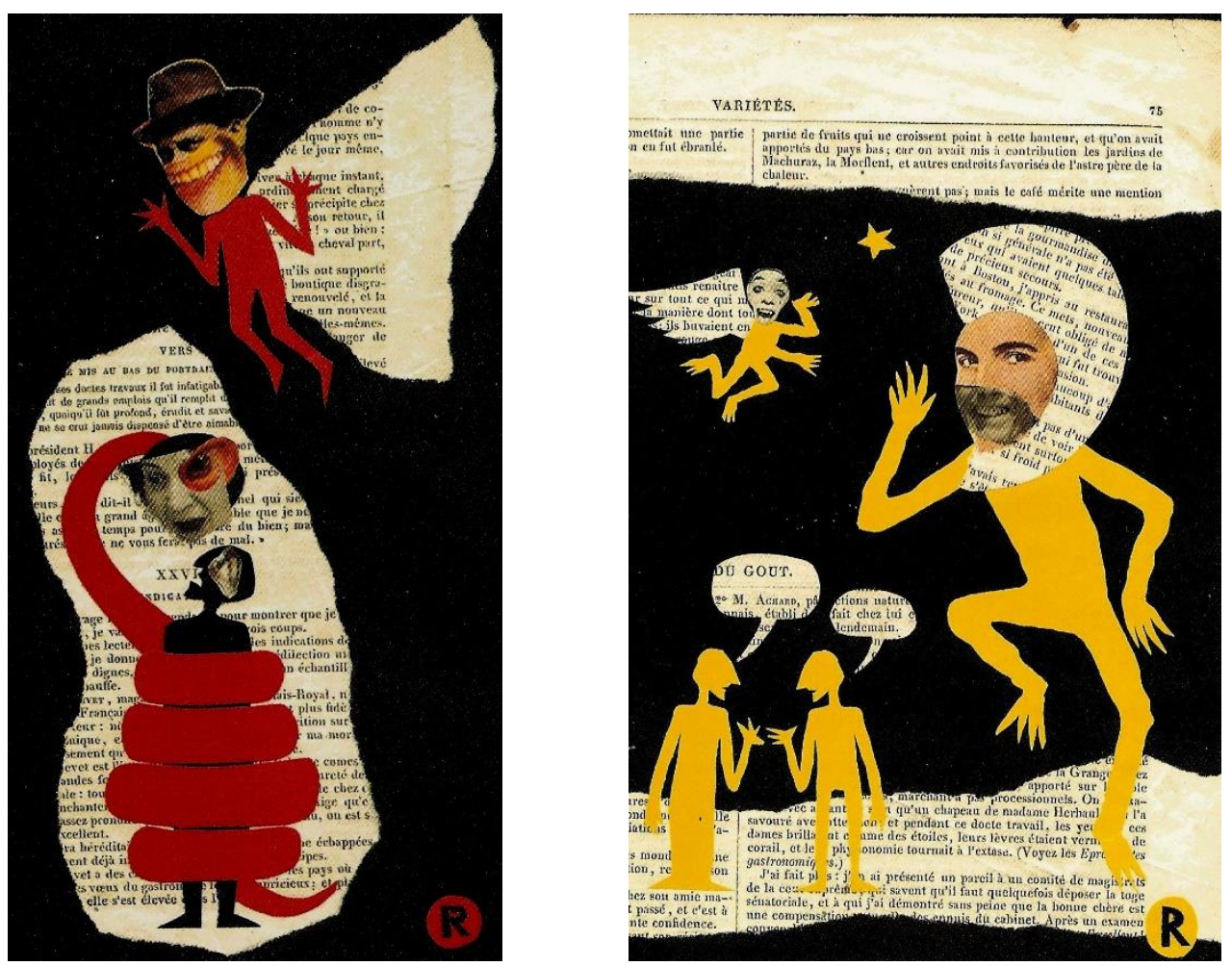

Retrato de $D$, por outro lado, sem qualquer elemento verbal, é uma colagem inscrita na tradição da arte $p o p$, onde se poderia até entrever o correlato plástico das referências musicais que encontramos nos primeiros livros do poeta, num procedimento técnico que virá a ter um aprofundamento bastante evidente dez anos depois, na série Manual do Condutor de Máquinas Sombrias.
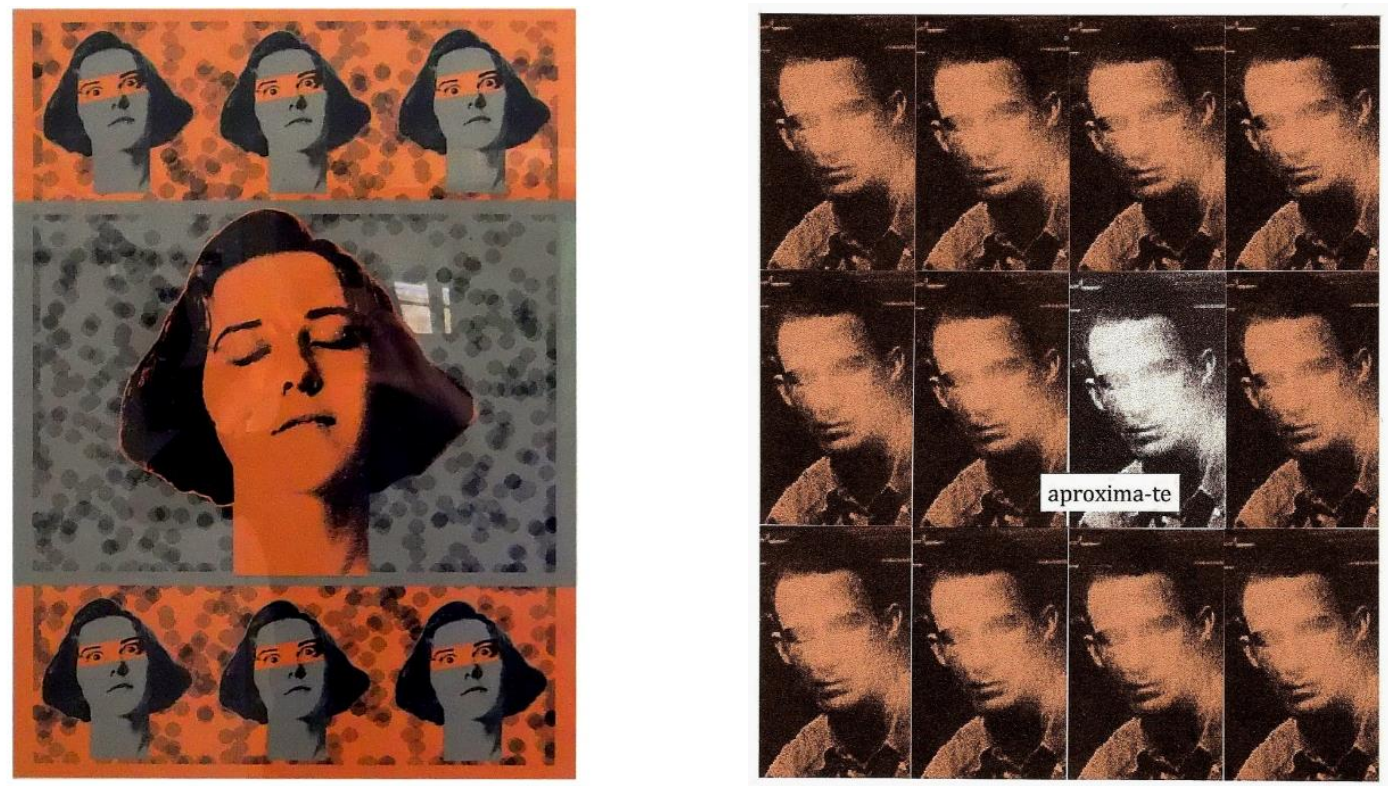

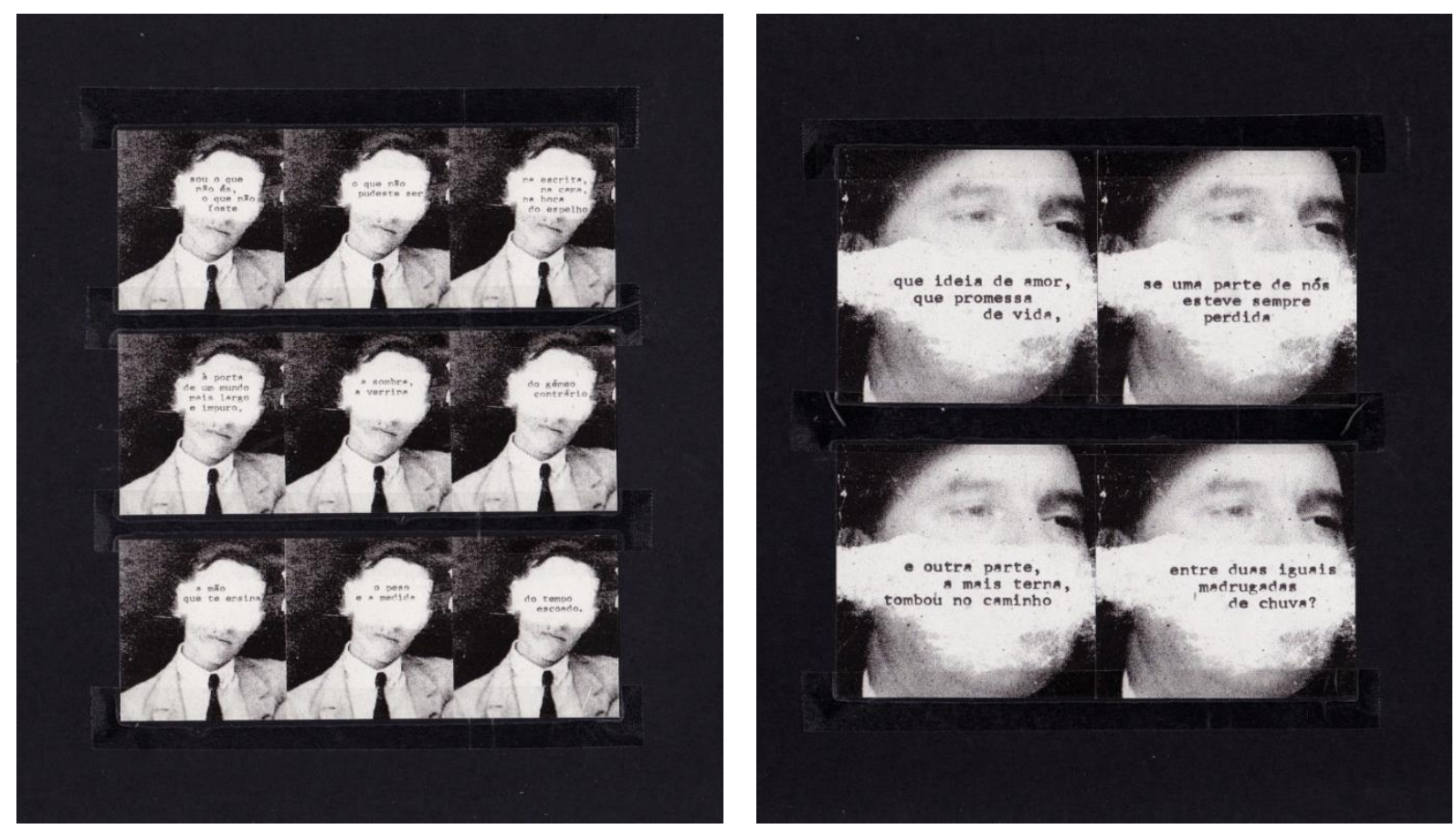

Ora, se a tradição plástica da collage parece ser um processo relativamente simples de reconstituir, mediante a sistematização histórica de uma linhagem que, partindo do cubismo, passará pelas expressões dada e surrealista, para sofrer uma transformação sóciocrítica na cultura pop dos anos 60 , o mesmo não se poderá dizer da colagem entendida em termos literários, cuja história e conceitos teórico-críticos parecem ser bem mais complicados de estabilizar. Curiosamente, até nesta matéria a distância entre a narra tiva e a lírica tende a agudizar-se e a agravar-se: qualquer estudo que se ocupe do conceito de "colagem narrativa" dará como exemplos as obras matriciais de Max Ernst, e prosseguirá, no caso português, aludindo aos trabalhos de Alexandre O'Neill em A Ampola Miraculosa ou de Mário Henrique Leiria em obras menos conhecidas, o que significa que "colagem narrativa" implica sempre a consideração de objectos produzidos a partir de um processo de combinação medial do texto e da imagem (pictórica ou fotográfica, como no caso especial dos photo-romans) que se associam em virtude de uma mútua organização sequencial; pelo contrário, a maior parte dos estudos que procuram reflectir sobre a historicidade e o escopo daquilo a que poderíamos chamar a "colagem poética", desde as reflexões fundadoras de Louis Aragon, tendem a circunscrever-se a objectos única e exclusivamente verbais validados pela prática artística das "palavras coladas" que excluem da colagem discursiva a 
verdadeira colagem matérica -, de origem assinalável na obra de Lautréamont ${ }^{4}$, nos poemas-conversação de Apollinaire ou nos poemas-elásticos de Blaise Cendrars, nas "tavole paroliberi" do Futurismo de Marinetti ou nas composições modernistas de T. S. Eliot e Ezra Pound, e com prolongamento significativo nas experiências efectivas e materiais de colagem de fragmentos de textos levadas a cabo pelos dada e surrealistas (com destaque para Tristan Tzara e André Breton ${ }^{5}$ e, no caso português, para Mário Cesariny de Vasconcelos ${ }^{6}$ ou, num outro contexto, Alberto Pimenta e António Aragão), bem como na técnica de cut-up teorizada e praticada por Brian Gysin e William Burroughs nos anos 50-60.

Quer isto dizer que a maior parte das reflexões em torno da noção de colagem entendida poeticamente acabam por a confundir com a montagem, mas sobretudo por se debruçar sobre o mecanismo intertextual da citação (e até do plágio), o que se torna ainda mais evidente quando lemos o primeiro capítulo da conhecida obra de Antoine Compagnon sobre o "trabalho da citação", precisamente intitulado "Tesoura e cola". Ora, este entendimento tem consequências decisivas no modo como a colagem poética assim se distancia do essencial da colagem plástica (ou collage), pois há que pensar que, como assinalou com toda a pertinência Gilles Dumoulin no seguimento das considerações decisivas de Louis Aragon7, ao sublinhar que "lá onde a colagem pictural libertava a pintura de si mesma [...], ao integrar [...] materiais estética e semiologicamente heterogéneos à tradicional 'pintura a óleo'”, a colagem poética circunscrita à citação como prática intertextual não liberta a poesia de si mesma (Dumoulin 2012: 11; trad. minha).

Este é sem dúvida o trabalho de respigador e de reciclagem que Rui Pires Cabral assume em todas as notas peritextuais que acompanham os livros aqui em causa, ao declarar (como de resto havia já feito em Oráculos de Cabeceira), que se apropriou de fragmentos de textos de obras tão díspares e improváveis quanto as de Stevenson e Jules Verne ou a 'NOVA GRAMMATICA DA LINGUA INGLEZA, ou A ARTE DE FALLAR E ESCREVER COM PROPRIEDADE E CORRECÇÃO O IDIOMA INGLEZ' (de Agostinho Neri da Silva, Nova Officina de João Rodrigues Neves, Lisboa, 1809). Neste aspecto, a natureza das relações intertextuais que Pires Cabral estabelece orienta-se toda no sentido da assunção do estatuto do "génio não-original" (e também não-intencional) que, segundo a análise recente de Marjorie Perloff no seu estudo Unoriginal Genius: Poetry by Other Means in the New 
Century, seria o grande traço característico da criação poética da actualidade, fundada no princípio aparentemente anti-poundiano do "make it (not) new" - isto é, do ready-made convertido em ready-written -, o que explica que haja alguns críticos que perspectivam a colagem como um procedimento moderno de significação ou "genes" pós-modernos (cf. Perloff 2010) ${ }^{8}$. Na verdade, como explicitou ainda Dumoulin, "lá onde a citação reenvia de forma mais ou menos explícita no seu uso [...] ao autor e ao texto, a 'colagem' pelo contrário desestrutura ou reagencia a noção de autor como referente - ou referência - do texto, e a do texto enquanto unicidade e homogeneidade, superfície lisa de inscrição da subjectividade" (op. cit.: 16; trad. minha) ${ }^{9}$. Naturalmente, esta muito específica morte do Autor adquire ainda outros contornos quando o processo de selecção dos recortes textuais que entram na composição da colagem é assumidamente aleatório, ou "ao acaso", como acontece com Rui Pires Cabral no caso de Oráculos de Cabeceira, ou em algumas colagens em que tal procedimento criativo parece ser a base da própria composição.

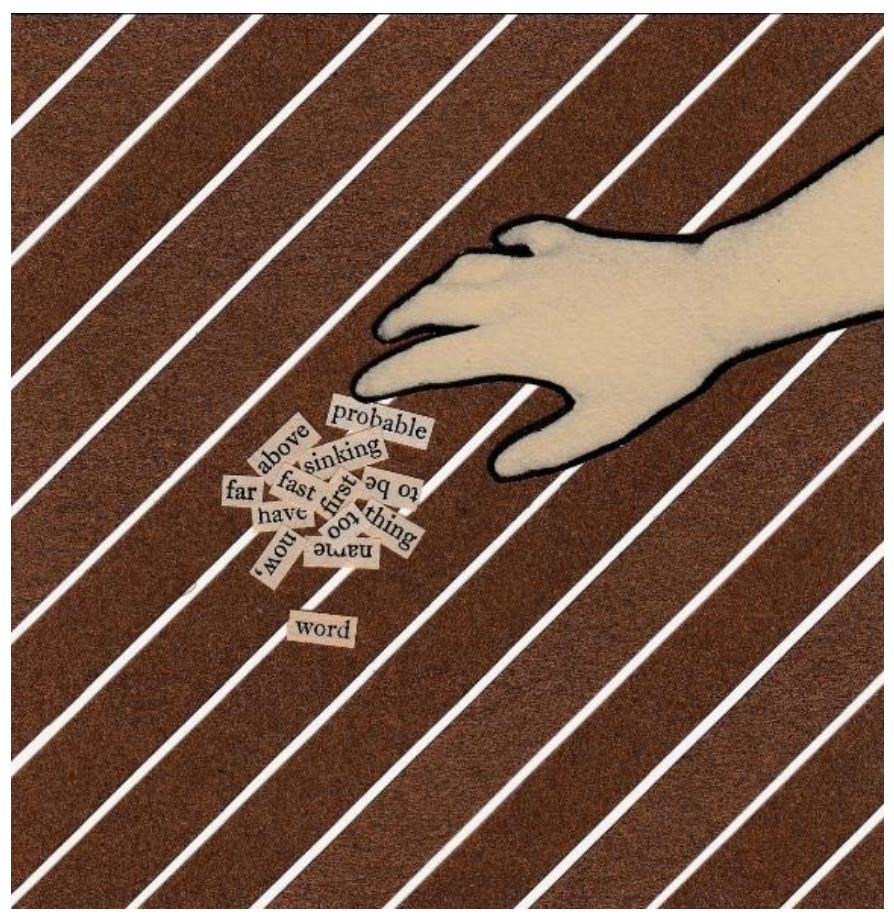

Hunting for poems on the kitchen table

Por outro lado, a assunção de que "recortar é viver", ou de que "recortar é escrever", faz também vincular o acto criativo ao acto crítico mais originário tal como o entendia Barthes ao lembrar que a função medieval do compilator implicava já uma estratégia de 
deformação textual assente apenas na citação e na segmentação que, segundo ele, são os actos primordiais de criação de um novo inteligível. Montaigne anunciou-o declaradamente no seu ensaio De La Physionomie, Benjamin demonstrou-o bem nas suas Passagens, Pedro Eiras tem-no demonstrado também em colagens críticas como a recente "Ah, a eterna mania das citações!", publicada na Revista ESC:ALA.

Mas não podemos esquecer ou ignorar aquilo que, no panorama poético e artístico da literatura portuguesa, marca a singularidade absoluta da obra recente deste Rui-mãosde-tesoura: nele, o conceito de "poema-colagem" não remete nunca para um objecto apenas verbal, porquanto o processo de colagem preserva a sua significação mais primitiva, que pressupõe a reunião num mesmo objecto artístico de elementos heterogéneos de proveniências díspares, em termos propriamente materiais: isto é, como nas colagens de Picasso e de Braque, mas com implicações bastante distintas, os poemas-colagem de Rui Pires Cabral compõem-se com base numa relação de combinação medial onde por vezes quase poderíamos entrever uma espécie de reformulação contemporânea do emblema humanista já revisto também pelos processos de legendagem surrealista, como fica bastante óbvio num livro como Elsewhere/Alhures ou nas últimas publicações do Autor no seu site, sob o título Gramática Ilustrada da Língua Portuguesa.

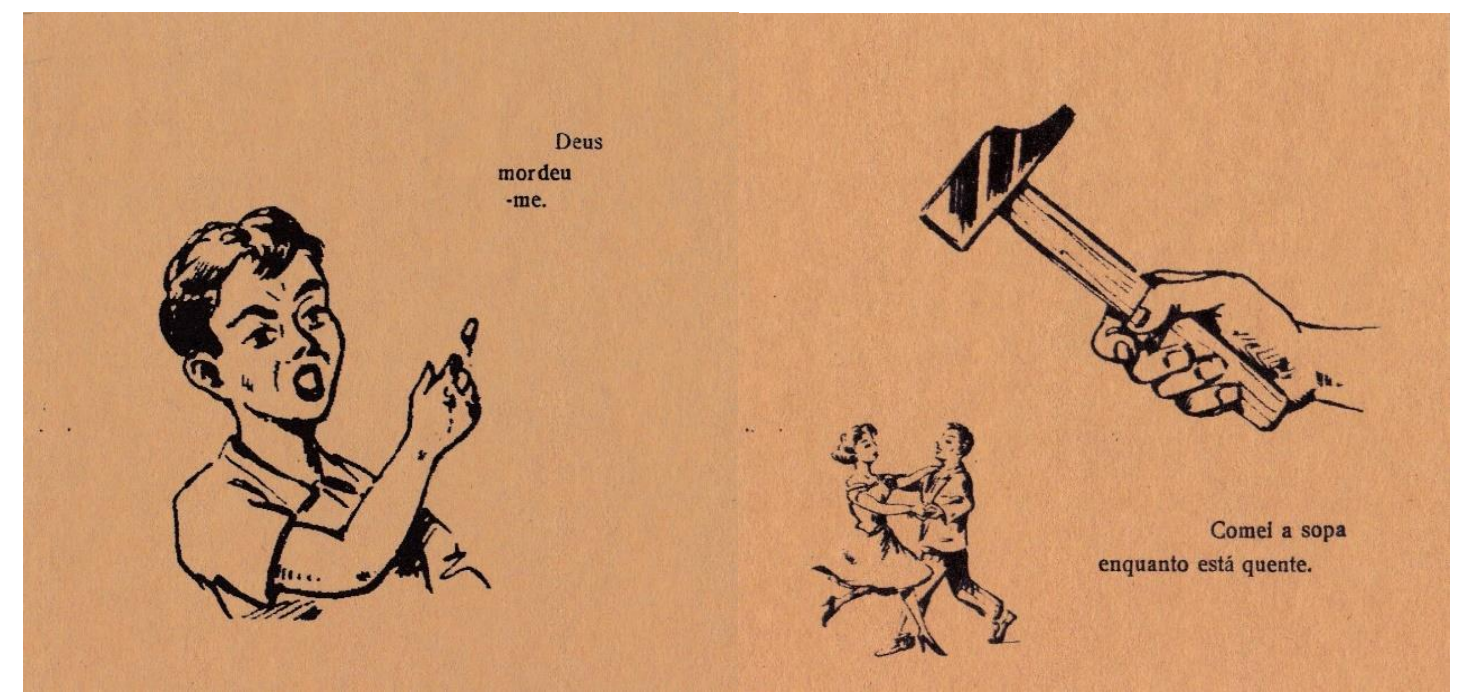

Acontece porém que esta estratégia de combinação medial ou de ekphrasis completiva $^{10}$, solicitando uma leitura sinóptica, apesar de poder ser unificada com base no 
conceito e na prática da colagem, não deixa de suscitar problemas críticos e epistemológicos bastante complexos, uma vez que as expressões que tais colagens assumem não são todas da mesma natureza. Notemos apenas, para abreviar o estado aberto desta arte, o seguinte:

-- as três secções de Biblioteca dos Rapazes exigem uma competência de leitura que terá de associar alguns princípios próprios da colagem narrativa a mecanismos compositivos do campo da banda desenhada ${ }^{11}$, conduzindo a uma meditação aprofundada sobre os limites do conceito de novela gráfica e da sua possível aplicabilidade ao domínio da poesia (com dificuldades acrescidas, uma vez que falar em "poesia gráfica" implica necessariamente, para lá do aparente pleonasmo que a própria estrofe ou o verso denunciam, aludir a uma organização gráfica da própria matéria verbal, como no âmbito da poesia concreta ou experimental);

-- já o volume Álbum desencadeia, a partir do próprio título, uma relação de legibilidade que pressupõe estratégias aproximadas da folagem e do photo-roman ou roman-photo (mais uma vez, tendo que ser pensado à luz da prática poética, o que obriga a uma problematização terminológica também bastante complexa), bem como a revitalização de uma tradição que remonta aos livros modernistas de foto-poesia de Maiakowsky e outros ${ }^{12}$, relação essa que se agudiza e dificulta com o fragmentarismo das imagens fotográficas em Oh! LUSITANIA, onde o processo de folagem parece ser dominante;

-- as imagens quebradas de Broken, por sua vez, com os seus buracos e espaços negros, vêm sintetizar todas estas inclinações e ainda reforçar o carácter de inacabamento próprio da colagem que Stardust mais do que todos evidencia, o que significa, do ponto de vista crítico, uma multiplicação tão rica quanto complexa dos problemas envolvidos na abordagem rigorosa da obra no seu novo lirismo, assim como na consideração das fron teiras da sua sintaxe visual: "O truque da colagem consiste... em nunca suprimir inteiramente a alteridade desses elementos reunificados numa composição temporária", lê-se no Manifesto do Grupo Um, de 1978 (apud Perloff 1986: 49). 
Em certa medida, as questões que se colocam são bastante próximas das que W. J. T. Mitchell assumiu terem-no perturbado ao equacionar o valor artístico da obra de William Blake: "a minha própria evolução", confidenciou o autor de Picture Theory, "foi inicialmente estimulada, não por um qualquer imperativo abstracto ou teórico, mas pelas necessidades concretas que implicava o estudo da obra de William Blake, pintor, poeta e gravador cuja arte compósita da 'impressão iluminada' exige que se pense para lá das fronteiras entre palavra e imagem, entre literatura e artes visuais" (Mitchell 2009: 3; trad. minha). Acresce que as colagens de Rui Pires Cabral interferem de um modo bastante decisivo na própria história da colagem na sua relação com o mundo e com o problema da representação, dado que Pires Cabral não opera, como fizeram os vanguardistas do início do século XX, com base na inserção na obra de elementos ou objectos do mundo real ${ }^{13}$, mas, pelo contrário, mais aproximado de Max Ernst na leitura de Aragon ${ }^{14}$, a partir da reconfiguração e do reagenciamento de materiais já originariamente representativos, como os textos e as fotografias. Neste sentido, parece ainda bastante pertinente e rentável do ponto de vista crítico equacionar a composição multímoda destes objectos à luz de certos procedimentos cinematográficos que jogam com o grau e a natureza da presença de um enunciado verbal numa imagem, conferindo à combinação medial uma verdadeira integração constitutiva: o intratítulo, inscrição verbal que pertence ao mundo ficcional, e que nesse sentido pode ser lido tanto pelo espectador quanto pela personagem; o sobretítulo, texto escrito sobre a imagem que emana da diegese mas é totalmente inacessível, na sua matéria e na sua forma, aos protagonistas (cf. Dubois 1999: passim).

Para terminar, apenas uma consideração: tenho algumas dúvidas que o neologismo "lisual", proposto por autores como David Gullentops e Jean-Pierre Bobillot, seja o conceito operatório mais indicado para a abordagem crítica renovada de criações como estas de Rui Pires Cabral. Mas não tenho dúvidas nenhumas que, quando W. J. T. Mitchell criou o conceito de imagemtexto, levando a cabo uma colagem verbal de significação crítica, estaria certamente a pensar em poemas-colagem como estes de Rui Pires Cabral: objectos onde imagem e texto não entram em ruptura, nem sequer em relação, mas sim em síntese. ${ }^{15}$ Objectos, em suma, que forçam o leitor a errar o caminho, sempre sem saber se aqui a colagem é para a poesia "um abrigo, ou um abismo" (Cabral 2012: 13). 

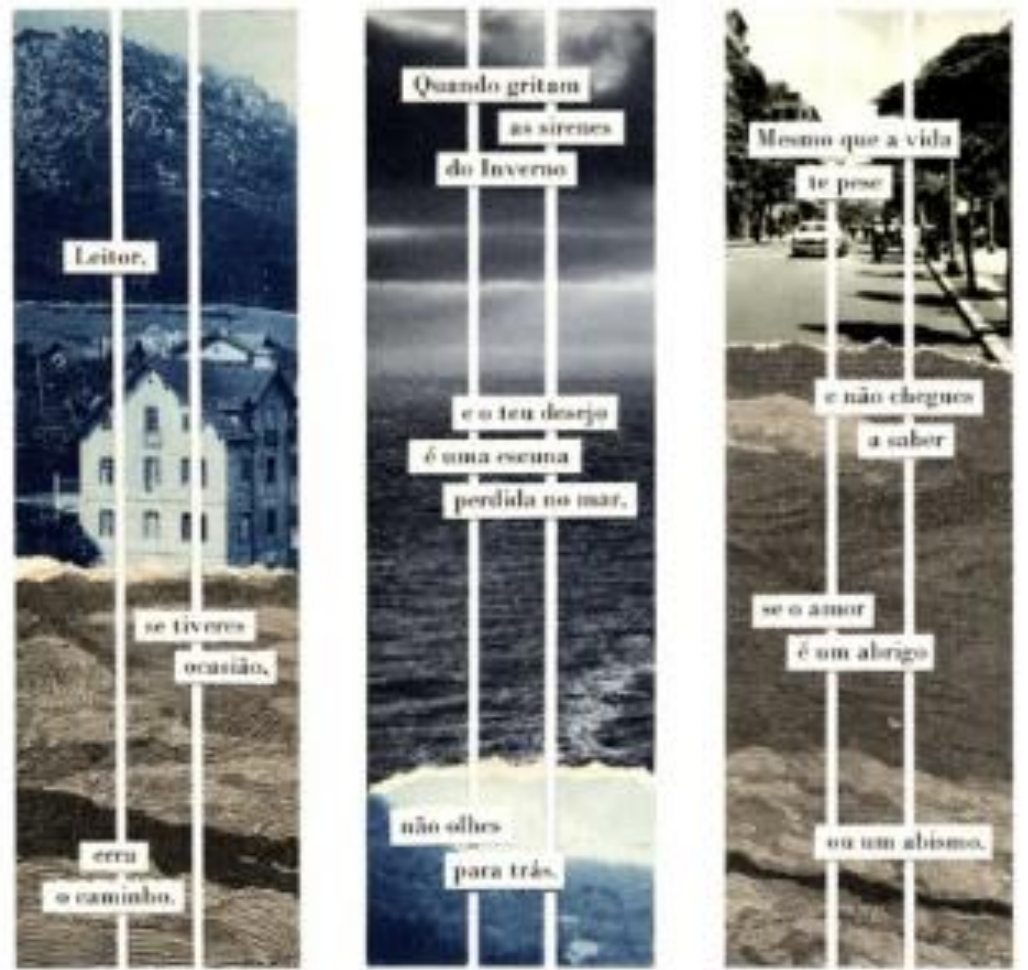


\section{Bibliografia}

Aa. Vv. (1989), Collage: Critical Views, ed. Katherine Hoffman, Ann Arbor, UMI Press.

Aa. Vv. (2012), The Future of Text and Image: Collected Essays on Literary and Visual Conjunctures, ed. Ofra Amihay e Lauren Walsh, Newcastle, Cambridge Scholars Publishing.

Aragão, António (1964), "Poesia encontrada”, Cadernos da Poesia Experimental, 1, Lisboa, Ed. Autor.

Aragon, Louis (1965), Les Collages, Paris: Hermann.

Baetens, Jan (2008), "Of graphic novels and minor cultures: the fréon collective", Yale French Studies, 114, Writing and the Image Today: 95-115.

Bobillot, Jean-Pierre (1998), "Du visuel au littéral: quelques propositions", in Aa. Vv., Poésure et Peintrie, Marseille, Musées de Marseille.

Breton, André (1969), Manifestos do Surrealismo, Lisboa, Moraes Editores.

Brockelman, Thomas P. (2001), The Frame and the Mirror: On Collage and the Postmodern, Evanston, Northwestern University Press.

Bürger, Peter (1993), Teoria da Vanguarda, Lisboa, Vega.

Cabral, Rui Pires (2012), Biblioteca dos Rapazes, Lisboa, Pianola.

-- (2013a), Álbum, Lisboa, Nenhures.

-- (2013b), Broken, Lisboa, Paralelo W.

-- (2013c), Stardust, Lisboa, Nenhures.

-- (2014a), "Desenganos", Colóquio/Letras, 185, Lisboa, Janeiro.

-- (2014b), Oh! LUSITANIA, Lisboa, Paralelo W.

-- (2015), Elsewhere/Alhures, Vila Real/Lisboa, (não) edições.

-- (2015), Morada, Lisboa, Assírio \& Alvim.

Cassé, Michel (1993), Du Vide et de la Création, Paris, Odile Jacob. 
Cocteau, Jean (1926), Le Rappel à I'Ordre, Paris, Librairie Stock.

Compagnon, Antoine (1979), La Seconde Main ou Le Travail de la Citation, Paris, Seuil.

Dubois, Philippe (1999), "L'écriture figurale dans le cinéma muet des années 20", in, Figure, Figural, dir. François Aubral e Dominique Château, Paris, L'Harmattan: 245-273.

Dumoulin, Gilles (2012), Du Collage au Cut-Up (1912-1959): Procédures de Collage et Formes de Transmédiation dans la Poésie d'Avant-Garde, Grenoble: Université de Grenoble.

Eiras, Pedro (2014), "Ah, a eterna mania das citações", ESC:ALA, 2, Junho. URL: https://escalanarede.com/2014/10/06/ah-a-eterna-mania-das-citacoes/

Evans, David (ed.) (2009), Appropriation, Whitechapel, Documents of Contemporary Art.

Ezquerro, Milagros (2010), "De I'hybridation féconde", Cahiers de Narratologie, 18. URL: http://narratologie.revues.org/6005

Gullentops, David (2001), Poétique du Lisuel, Paris, Editions Paris-Méditerranée.

Krauss, Rosalind (1981), "In the Name of Picasso", October, vol. 16: Art World Follies: 5-22.

Lautréamont, Isidore Ducasse, Comte de (1973), Oeuvres Complètes, Paris, Gallimard.

Lima, Sergio (2016), O Rasgo Absoluto, Coimbra, Debout sur l’Oeuf.

Lopes, Silvina Rodrigues (1994), A Legitimação em Literatura, Lisboa, Cosmos.

Mitchell, W. J. T. (2009), “Iconologie, culture visuelle et esthétique des médias”, Perspective, 3. URL: http://perspective.revues.org/1301

Montémont, Véronique (2008), "Dites voir (sur l'ekphrasis)", in Aa. Vv., Littérature et Photographie, Rennes, Presses Universitaires de Rennes: 455-472.

Moura, Pedro (2013), «Biblioteca dos Rapazes, Rui Pires Cabral», Cadeirão Voltaire. URL: https://cadeiraovoltaire.wordpress.com/2013/02/17/visitas-no-cadeirao-8/

Perloff, Marjorie (1986), The Futurist Moment: Avant-Garde, Avant-Guerre, and the Language of Rupture, Chicago, University of Chicago Press.

Perloff, Marjorie (1998), "Collage and poetry", in Encyclopedia of Aesthetics, vol. 1, ed. Michael Kelly, New York, Oxford University Press. 
Perloff, Marjorie (2010), Unoriginal Genius: Poetry by Other Means in the New Century, Chicago: The University of Chicago Press.

Pimenta, Tamy de Macedo (2015), “Apropriação e indeterminação na poesia de Rui Pires Cabral: da memória pessoal à 'inspiração mais material possível'", Cadernos de Letras da UFF: Dossiê Literaturas de Língua Portuguesa em Diálogo, 50: 219-237.

Rajewsky, Irina O. (2005), "Intermediality, intertextuality, and remediation: a literary perspective on intermediality", Intermédialités: Histoire et Théorie des Arts, des Lettres et des Techniques / Intermediality: History and Theory of the Arts, Literature and Technologies, 6: Remédier / Remediation (dir. Philippe Despoix et Yvonne Spielmann): 43-64.

Santos, Hugo Pinto (2014), "Algures numa enseada do verdadeiro mundo já nos esperava ninguém", Público: Ípsilon, Lisboa, 8 de Janeiro.

Wescher, H. (1976), La Historia del Collage: Del Cubismo a la Actualidad, Barcelona, Gustavo Gili.

Joana Matos Frias é Professora Auxiliar na Faculdade de Letras da Universidade do Porto onde se doutorou em 2006 com a dissertação Retórica da Imagem e Poética Imagista na Poesia de Ruy Cinatti - , membro do Instituto de Literatura Comparada Margarida Losa, membro da Direcção da Sociedade Portuguesa de Retórica, investigadora da rede internacional LyraCompoetics e colaboradora do grupo «Poesia e Contemporaneidade» (Universidade Federal Fluminense). Autora do livro O Erro de Hamlet: Poesia e Dialética em Murilo Mendes(7letras, 2001) - com que venceu o Prémio de Ensaio Murilo Mendes -, responsável pela antologia de poemas de Ana Cristina César Um Beijo que Tivesse um 
Blue (Quasi, 2005), co-responsável (com Luís Adriano Carlos) pela edição fac-similada dos Cadernos de Poesia (Campo das Letras, 2005), e (com Rosa Maria Martelo e Luís Miguel Queirós) pela antologia Poemas com Cinema (Assírio \& Alvim, 2010). Tem publicado ensaios no campo da Poesia Portuguesa e da Poesia Brasileira modernas e contemporâneas privilegiando as correlações entre a poesia, a pintura, a fotografia e o cinema - e a sua actividade crítica tem-se repartido por autores como Ronald de Carvalho, Cecília Meireles, C. Drummond de Andrade, Vinicius de Moraes, Guimarães Rosa, Clarice Lispector, Murilo Mendes, J. Cabral de Melo Neto, Adélia Prado, Ana Cristina Cesar, Angélica Freitas, Marília Garcia, Fernando Pessoa, Almada Negreiros, José Régio, José Gomes Ferreira, Eugénio de Andrade, Vergílio Ferreira, Nuno Guimarães, Ruy Belo, Fiama Hasse Pais Brandão, Armando Silva Carvalho, António Franco Alexandre, Manuel António Pina, Daniel Faria, Vasco Gato, Rui Pires Cabral e José Miguel Silva. Em 2014-2015, publicou as colectâneas de ensaios Repto, Rapto e Cinefilia e Cinefobia no Modernismo Português.

\section{NOTAS}

\footnotetext{
${ }^{1}$ Como sublinhou já Hugo Pinto Santos: “Nos poemas de Broken, Rui Pires Cabral volta a pôr em jogo essa 'questão/ simplesmente topográfica' (A Super-Realidade, Língua Morta) que tantos dos seus livros replicam Capitais da Solidão (Teatro de Vila Real, 2006) seria apenas o exemplo mais óbvio, mas há rastos luminosos em livros como Praças e Quintais (Averno, 2003), para nada repetir sobre o já referido Música Antológica e Onze Cidades" (Santos 2014: s/p).

${ }^{2}$ Perloff (1998: s/p): “collage subverts all conventional figure-ground relationships, it generally being unclear whether item $A$ is on top of item B or behind it or whether the two coexist in the shallow space which is the 'picture'".
} 
${ }^{3}$ N.B. Cocteau (1926 :117): "Voici enfin la ressemblance et non le trompe-l'œil, le trompe-l'esprit après la déformation qui gêne notre regard".

${ }^{4}$ N.B. Lautréamont na segunda parte das suas Poesias, em versos revisitados por Aragon, que neles vê toda a "moral da colagem": "Le plagiat est nécessaire. Le progrès l'implique. Il serre de près la phrase d'un auteur, se sert de ses expressions, efface une idée fausse, la remplace par l'idée juste" (Lautréamont 1973: 306; cf. Aragon 1965: 59).

${ }^{5}$ N.B. André Breton, no Manifesto do Surrealismo de 1924: «Les papiers collés de Picasso et de Braque ont même valeur que l'introduction d'un lieu commun dans un développement littéraire du style le plus châtié. II est même permis d'intituler POÈME ce qu'on obtient par l'assemblage aussi gratuit que possible (observons, si vous voulez, la syntaxe) de titres et de fragments de titres découpés dans les journaux».

${ }^{6}$ Cf. Mário Cesariny, Uma Combinação Perfeita, Lisboa, Prates, 1995.

${ }^{7}$ Louis Aragon, "Collages dans le roman et dans le film” (1965): “[...] à partir du moment où nous considérons l'existence de collages dans un art non-plastique, le poème, le roman, de l'alphabet signé à une lettre ramassée dans la rue, nous sommes fatalement amenés à confondre collage et citation, à nommer collage le fait de plaquer dans ce que j'écris ce qu'un autre écrivit, ou tout texte tiré de la vie courante, réclame, inscription murale, article de journal, etc... [...] Si je préfère l'appellation de collage à celle de citation, c'est que l'introduction de la pensée d'un autre, d'une pensée déjà formulée, dans ce que j'écris, prend ici, non plus valeur de reflet, mais d'acte conscient, de démarche décidée, pour aller de ce point d'où je pars, qui était le point d'arrivée d'un autre".

${ }^{8}$ Cf. Kim Levin in Collage: Critical Views (1989: xix): "From our vantage point near the end of the century we can now begin to see that collage has all along carried postmodern genes. Pieced together with byproducts from the modern world, collage - the most literally materialistic of mediums - has always contained information that pointed beyond modernism. The germs of appropriation and simulation can be found in the earliest recycled scraps of Cubist collages"; cf. Thomas P. Brockelman, The Frame and the Mirror: On Collage and the Postmodern.

9 Na síntese de Gilles Dumoulin: "Le collage rejoint, sur le plan littéraire, une forme de ready-written: l'appropriation d'un texte 'déjà écrit', sans autre modification - si ce n'est que dans ce cas il ne s'agit pas d'un texte, mais d'un alphabet, d'un objet linguistique représentant les éléments de première articulation auxquels on accorde un poids symbolique, s'attachant plus à la valeur sémiotique de l'objet, qu'à sa sémantique. A la différence de la citation qui établit une relation binaire entre deux textes et deux auteurs, selon divers degrés d'intertextualité et de références induisant une reconnaissance du style et de l'autorité - y compris dans la démarche 'carnavalesque' de la parodie (Genette) - le collage, dans une pratique proprement révolutionnaire, efface l'importance de l'auteur (cité ou citant) et accorde à tout objet discursif, de fait, le statut de litté rarité. D'autre part, la technique du collage place le texte dans un fonctionnement essentiellement polyphonique, 
déstructurant le 'sujet' (l'auteur comme subjectivité) comme origine du sens et maîtrise du discours: le collage n'établit plus un lien d'autorité (dans tous les ordres du diagramme: de l'auteur au texte, comme d'auteur à auteur ou de texte à texte), mais accentue le travail d'agencement de différents discours" (Dumoulin 2012: 17).

${ }^{10}$ De acordo com a proposta de Véronique Montémont no ensaio "Dites voir (sur l'ekphrasis)" (2008), onde distingue a ekphrasis substitutiva (sem suporte iconográfico) da ekphrasis completiva (complemento do suporte iconográfico).

${ }^{11}$ N.B. Pedro Moura (2013): "Cada uma dessas tiras apresenta linhas no seu interior, transformando-as em três tiras menores no interior da 'estrofe', como se se tratassem de versos (se bem que o papel dos sulcos esteja a ser preenchido, com mais propriedade, por esses espaços em branco, que poderão fazer-nos recordar o espaço intervinhetal, mas não por isso menos construtor de significado, da banda desenhada, que também atravessa esta Biblioteca)".

${ }^{12}$ Cf. sobretudo, de Mayakovsky e Rodchenko's, About This, de 1923; de Nezval e Teige, Alphabet, de 1926; e o inédito de Mayakovsky e Rozhkov To the Workers of Kursk, de 1924-1927.

${ }^{13}$ N.B. Aragon: "L'histoire des collages sans doute n'est pas celle du realisme: mais l'histoire du realisme ne pourra demain s'6crire sans celle des collages. En ceci, reside ma perfidie" (1965: 149). E Marjorie Perloff (2010: 49): "each element in the collage has a dual function: it refers to an external reality even as its compositional thrust is to undercut the very referentiality it seems to assert".

14 "Chez Max Ernst, il en va tout autrement. Les éléments qu'il emprunte sont surtout des éléments dessinés, et c'est au dessin que le collage supplée le plus souvent. Le collage devient ici un procédé poétique, parfaitement opposable dans ses fins au collage cubiste dont l'intention est purement réaliste. Max Ernst emprunte ses éléments surtout aux dessins imprimés, dessins de réclame, images de dictionnaire, images populaires, images de journaux. Il les incorpore si bien au tableau qu'on ne les soupçonne pas parfois, et que parfois au contraire tout semble collage, tant avec un art minutieux le peintre s'est appliqué à établir la continuité entre l'élément étranger et son oeuvre. Enfin la photographie lui fournit aussi des éléments sans précédents dans la peinture. Tous ces éléments serviront à Ernst pour en évoquer d'autres par un procédé absolument analogue à celui de l'image poétique" (Aragon 1965: 18).

${ }^{15}$ Cf. W. J. T. Mitchell, "Image X Text", Introdução a The Future of Text and Image: Collected Essays on Literary and Visual Conjunctures (2012: 1 ss.). 